\title{
LUTAS IDEOLÓGICAS E MUDANÇA SOCIAL ${ }^{1}$
}

Maria de Fatima Felix Rosar ${ }^{2}$

\section{RESUMO:}

A reflexão que se apresenta no presente texto está focada no significado histórico do impasse entre a ideologia defendida pelos educadores adeptos de uma concepção revolucionária e a prática que se materializa no cotidiano da escola. Buscando apreender os elementos históricos e ideológicos dos movimentos revolucionários do Século XVIII e XIX, pretende-se destacar processos para o fortalecimento da formação da vontade coletiva, no sentido de superar os limites históricos da sociedade capitalista, em direção ao socialismo.

Palavras-chave: história, ideologia, política, mudança social, educação, socialismo

\section{IDEOLOGICAL STRUGGLE AND SOCIAL CHANGE}

\begin{abstract}
:
The reflection which is presented in this text is focused on the historical significance of the impasse between the ideology defended by educators knowledgeable about revolutionary concepts and the practice which materializes in the day to day running of schools. It seeks to grasp the historical and ideological elements of the revolutionary movements of the 18th and 19th centuries and aims to highlight processes which may strengthen the creation of the collective will insofar as it can overcome the historical limits of capitalist society and move in the direction of socialism.
\end{abstract}

Keywords: history, ideology, politics, social change, education, socialism

\section{1 - Introdução}

O interesse em tratar, embora preliminarmente, o tema da ideologia na perspectiva da mudança social se deriva de problemas que se apresentam no cotidiano do educador de um modo geral e, mais particularmente, daquele que busca na articulação entre teoria e prática a mediação do coletivo, com a finalidade de imprimir ao seu trabalho uma direção política adequada ao processo de construção de uma ordem social igualitária e democrática.

Inserido no âmbito da superestrutura, o educador comumente tem dificuldade de apreender a condicionalidade histórico-social das concepções, das teorias que perpassam toda a sociedade e, sobretudo a escola.

Mesmo que se considere o descenso do idealismo, como forma ideológica predominante na área da educação, a complexidade do processo de produção material e ideológica de cada momento histórico da fase do capitalismo monopolista e do imperialismo amplia o impasse entre teoria e prática.

Dessa forma, ainda que o materialismo histórico ganhe cada vez mais penetração em nível teórico no âmbito da educação no Brasil, o distanciamento entre posições teóricas e atividades práticas ameaça reduzi-lo a uma tendência idealista.

Ora, esse impasse tem substancialidade concreta, que se produz historicamente como resultado da dialética entre a infraestrutura e a superestrutura. Mas se o impasse resulta do próprio movimento dialético entre os vários níveis da realidade, esse, por sua 
vez, resulta do enfrentamento das classes sociais e nesse enfrentamento as armas ideológicas tem a capacidade de aumentar ou diminuir o impasse, cuja solução está contida na superação da luta entre as classes.

Contraditoriamente, as classes dominantes tentam minimizar o impasse, alterando ora as condições materiais, ora as superestruturais, pressionadas que são pelo avanço das classes revolucionárias, que produzem como efeito prático de sua ação o acirramento da contradição social.

A escola, como os demais aparelhos ideológicos, é o lócus privilegiado das lutas ideológicas da sociedade de classe, portanto, impõe-se ao educador a tarefa pedagógica e política de assumir concretamente a sua opção ideológica.

No caso de uma opção progressista, interessa ao educador, na perspectiva do intelectual orgânico, entender como as ideologias ganham força material para a construção de um novo bloco histórico. No entanto, isso implica reconhecer a existência de um amplo espectro ideológico, que se evidencia nas mais contraditórias formas de expressão, difusão e absorção de ideologias das diversas frações de cada classe social da sociedade capitalista na sua fase monopolista.

Para essa intrincada tarefa, o educador necessita se apropriar do materialismo histórico ou da filosofia da práxis, que no dizer de Gramsci "se realiza no estudo concreto da história e na atividade atual da criação de uma nova história”. (1981, p. 151)

Nesse sentido, optei pelo estudo de alguns momentos históricos que foram expressões concretas das lutas ideológicas entre burguesia e o proletariado, procurando no passado um maior conhecimento do presente.

Retomei os textos de Marx sobre a Revolução Francesa, de Gramsci em que realiza análises histórico-políticas, de Lukács sobre o irracionalismo como corrente dominante da filosofia burguesa reacionária da Alemanha no século XIX, de Hobsbawm e Florestan para compreender mesmo parcialmente, porque o liberalismo ainda permanece, embora sob formas variadas, a predominar como a ideologia do nosso século.

Alguns aspectos que privilegiei nesse estudo estão relacionados ao atraso dos movimentos ideológicos das massas em relação à situação econômica, à penetração da ideologia dominante nas camadas inferiores, à rearticulação da ideologia burguesa no embate com a ideologia do proletariado, à efetividade da ideologia revolucionária, à necessidade histórica da aliança entre operários e camponeses, e às condições de formação da vontade coletiva para superação da sociedade capitalista.

$\mathrm{O}$ resultado desse estudo preliminar deixa à mostra os limites teóricometodológicos que não consegui superar, portanto, contém o inconformismo de quem se submetendo ao desenvolvimento da história, tenta superar a sua própria defasagem histórica, por aproximações sucessivas, sabendo a priori que esse processo é infindável.

\section{2 - Primeiras lutas: formação das classes sociais e das suas ideologias nos séculos XVIII e XIX}

As lutas entre o proletariado e a burguesia datam do século XVIII, quando o colapso do feudalismo traz à tona o confronto entre a classe média (intermediária) e a Monarquia, a nobreza, a Igreja.

Os séculos XVIII e XIX abarcaram duas situações históricas determinantes para o desenvolvimento histórico da Europa e de todo o mundo. A Revolução Francesa e a Revolução Industrial sintetizam os múltiplos fatores de mudança social, que alteraram os sistemas econômicos, políticos e sociais das grandes potências e, também, dos Estados menores, embora de forma diferenciada. 
O domínio do absolutismo e do tradicionalismo religioso foi abalado pelo acelerado ritmo do progresso econômico e tecnológico que comprova a predominância das forças materiais sobre as "forças divinas". Apesar da reação dos príncipes e monarcas, mediante as chamadas reformas para modernização, difundiu-se o iluminismo como ideologia revolucionária daqueles segmentos mais ligados ao comércio, à indústria, à produção de conhecimento, enfim à expansão capitalista, organizados em sociedades como as lojas de franco-maçonaria.

O iluminismo constituía o primeiro avanço ideológico no sentido da afirmação da ordem burguesa contra a ordem monárquica vigente e, por isso, foi também absorvido por monarcas esclarecidos, como os da Dinamarca e de Savóia, que determinaram a abolição da servidão antes de 1789 .

No entanto, a força do iluminismo ultrapassa os limites dos anciens régimes;não pela força das idéias em si, mas pela força do movimento real que as produzia. A expansão demográfica, o crescimento do comércio além-mar, o florescimento da pequena indústria e da ciência transformavam a relação entre campo e a cidade, bem como as relações entre camponeses e proprietários da terra, operários e burgueses, nobres e monarcas.

Justamente onde esse progresso se deu de forma mais acelerado como na Inglaterra e França é que o iluminismo ganhou solidez, sendo componente ideológico da Revolução Industrial e da Revolução Francesa. Embora tivesse como objetivo libertar todos os indivíduos, essa ideologia dos escalões médios da sociedade estava condicionada aos limites do progresso desejado pela burguesia para expansão do capitalismo.

De fato, na Inglaterra onde a monarquia já havia sido destruída, onde a política estava subordinada aos interesses econômicos e já havia regulado as relações comerciais no campo e na cidade, o iluminismo tinha um caráter mais científico e menos revolucionário. Por outro lado, na França os seus slogans foram adotados pela Revolução Francesa e ganharam um conteúdo diferenciado para os burgueses e para o proletariado, cujo germe revolucionário estava nos jacobinos e nos "sansculottes" e nas propostas radicais de uma democracia iguaitária, que foram dissolvidas de imediato na Constituição de 1791, quando se instituiu a monarquia constitucional.

O modelo da Revolução Francesa foi exportado pela própria França, que pretendia liderar a libertação européia dos anciens régimes, enquanto tentava conter internamente as forças mais radicais.

No exterior, o jacobinismo foi assimilado pelas classes médias e instruídas, mas não logrou penetração nas camadas inferiores, a não ser na Inglaterra onde foi um movimento tipicamente operário, tendo, no entanto, se limitado às reivindicações econômicas e à luta contra os franceses considerados adversários eternos.

Esse fato possibilita uma avaliação daquilo que concluiu Gramsci sobre os movimentos revolucionários de massa, quando analisa alguns aspectos do economismo. $\mathrm{Na}$ crítica à convicção de que as leis objetivas como as leis naturais dão conta do desenvolvimento histórico, Gramsci diz:

Nestas maneiras de pensar não se leva em conta o fator "tempo" e, em última análise, a própria 'economia" no sentido de não se compreender que os movimentos ideológicos de massa estão sempre atrasados em relação aos fenômenos econômicos de massa e de que, portanto, em determinados momentos, o impulso automático devido ao fator econômico é afrouxado, travado ou até destruído momentaneamente por elementos ideológicos tradicionais; e que por isso deve haver luta consciente e determinada a fim de que se "compreenda" as exigências da posição econômica de massa que pode estar em contradição com as 
diretivas dos chefes tradicionais. Uma iniciativa política apropriada é sempre necessária para libertar o impulso econômico dos entraves da política tradicional, para modificar a direção política de determinadas forças que devem ser absorvidas para criar um bloco histórico econômico-político novo, homogêneo, sem contradições internas (GRAMSCI, 1980, 40)

Com essa observação de Gramsci para o estudo das ideologias é que se torna possível compreender também, porque o movimento jacobino na França, embora mais avançado do que o jacobinismo britânico teve uma vitória fugaz com a sua ditadura. Neste caso, tanto quanto no caso da Inglaterra, apesar da peculiaridade do desenvolvimento capitalista de cada um, faltava uma direção política para libertar do entrave econômico as massas em luta.

Na realidade, a República Jacobina de 1793 emergiu e se manteve muito mais pela situação de crise geral, pelos resultados da guerra da França com a maior parte da Europa, do que pelo apoio das massas, pois aterrorizados pela guerra e atingidos pelo confisco de alimentos, os camponeses retiraram o seu apoio ao Comitê de Salvação Pública, sob o comando de Robespierre, contribuindo para o fracasso da República.

Nas ruas e no parlamento francês se reproduziram as lutas entre o velho e o novo regime, sob o controle da burguesia, que, jogando de forma hábil com seus aliados, evitou o avanço dos jacobinos, derrotando-os até 1871, quando seus herdeiros: os operários instituíram o primeiro governo proletário - A Comuna de Paris.

No entanto, mesmo com a hegemonia dos liberais moderados, a França de fato exerceu uma função revolucionária em quase toda a Europa, onde sob o domínio do Império napoleônico foram implantadas as instituições burguesas e destruído o feudalismo. A Alemanha, a Bélgica, a Holanda, a Savóia, Luebeck, o Piemonte, Nápoles, Espanha, Renânia e Polônia foram submetidas à conquista francesa no período de 1799 a 1815, sendo que no mesmo período as coalizões contra a França das quais participaram a Áustria, Prússia, Rússia, Grã-Bretanha, tentaram derrotar Napoleão, o que veio a acontecer somente na guerra com a Rússia.

Após a derrota de Napoleão, só a queda dos Bournbons, em 1830, marca o inicio de outra onda revolucionaria, maior do que a anterior, porque mais radical, com a participação de classe operária, que crescera e se organizara na Inglaterra e na França.

O processo acelerado de expansão do capitalismo em toda a Europa, aliado aos movimentos de Independência na América Latina e em alguns países europeus como a Bélgica, como também a influência da democracia americana impunham a transformação dos sistemas políticos que impediam a mudança social.

Segundo Hobsbawn,

Havia vários modelos semelhantes, embora fossem todos originários da experiência francesa entre 1789 e 1797. Eles correspondiam às três principais tendências da oposição depois de 1815: o liberal ou moderado (ou em termos sociais o da classe média superior e da aristocracia liberal), o democrata radical (ou, em termos sociais, o da classe média inferior, parte dos novos industriais, intelectuais e pequena nobreza descontente) e o socialista (ou, em termos sociais, dos "trabalhadores pobres", ou das novas classes operárias industriais.

(...)A inspiração para o primeiro foi a Revolução de 1789-91, sendo seu ideal político o tipo de monarquia constitucional semibritânica com um sistema parlamentar de qualificação por propridedade e, portanto 
oligárquico que a Constituição de 1791 introduziu e que, como vimos, tornou-se o tipo padrão de Constiuição na França, na Grâ- Bretanha e na Bélgica depois de 1830/32. A inspiração para o segundo poderia ser descrita como a Revolução de 1792/3, sendo seu ideal político uma Republica democrática com uma inclinação para o "estado de bem estar social" e alguma animosidade em relação aos ricos o que corresponde à constituição jacobina ideal de 1793. (...) A inspiração para o terceiro foi a revolução do Ano II e as insurreições pós-termidorianas, sobretudo a Conspiração dos Iguais de Babeuf, significativo levante de jacobinos extremados e de primeiros comunistas, que marca o nascimento da moderna tradição comunista na política. (HOBSBAWN, 1981, 130-1)

Portanto, a partir de 1830, as classes sociais já se encontravam mais definidas, bem como os seus interesses econômicos e políticos, que se expressavam em formas ideológicas diversificadas, dado que a esquerda e a direita lutavam por objetivos antagônicos: a revolução social e a restauração respectivamente.

Embora os movimentos revolucionários de 1830-48 fossem considerados minoritários, pois dele participavam a classe média e os intelectuais, mas não as massas, a sua repercussão e ampliação se davam pelo seu caráter internacional. O objetivo das organizações de conspiradores como os carbonari, os blanquistas e os dezembristas era a revolução social em toda a Europa.

De outro lado, os liberais moderados lutavam pelo fortalecimento da monarquia constitucional, distanciando-se dos seus antigos aliados: os republicanos, os radicais e os proletários cuja bandeira era a república social e democrática. Ao mesmo tempo, os radicais democratas e os da extrema esquerda disputavam a conquista das massas para as lutas revolucionárias.

A correlação de forças que se estabeleceu entre essas classes e suas tendências políticas e ideológicas desencadeou a insurreição de 1848 na França, sob o controle momentâneo dos operários. Uma série de revoluções simultâneas nos mais diferentes países, realizou por um breve período, o modelo de uma "revolução mundial" ou a "primavera dos povos", como denominou Hobsbawn.

O panorama mundial, após esse período, apontou a derrota de seus protagonistas: os trabalhadores. Mais uma vez foi possível avaliar o poder dos antigos regimes sob o comando dos liberais moderados e uma relativa passividade das massas camponesas, com exceção da Hungria, onde após a derrota da revolução, eles realizaram praticamente uma guerrilha rural. Somente, em agosto de 1849, a revolução húngara foi sufocada por Viena com o auxílio do exército russo.

$\mathrm{Na}$ Itália e na Alemanha a revolução ocorrera simultaneamente ao movimento de unificação nacional, portanto, a derrota dos radicais resultou de duas forças políticas insuperáveis: dos liberais moderados (interna) e dos adversários externos (os austríacos).

A Prússia submeteu-se mais uma vez à monarquia dos Habsburgos, enquanto na França os liberais e conservadores, assumindo a sua identidade de classe dirigente instituíram o "partido da ordem" e tomaram posse do poder.

A restauração dos regimes conservadores permitiu uma ampla liberalização no setor econômico, um crescimento extraordinário do comércio e da indústria, além do fortalecimento definitivo da ordem burguesa, cujo potencial revolucionário esgotara-se na sua realização.

Os desdobramentos da Revolução Francesa permitem um maior aprofundamento sobre a constituição da força revolucionária do proletariado, que apesar de ter participado 
efetivamente das insurreições de 1848, carecia de organização e de uma sólida ideologia política, que lhe permitisse alcançar a direção do movimento revolucionário das massas.

O grande contingente dos radicais era constituído por artesãos, pequenos proprietários, agricultores e os intelectuais que assumiam a liderança do movimento revolucionário, embora seu radicalismo fosse vacilante e até menos avançado do que a posição dos estratos menos instruídos, cujos objetivos eram alcançar

Uma constituição democrática de estado, fosse constitucional ou republicana, fornecendo-lhes a maioria para si e seus aliados camponeses, assim como um governo democrático local que lhes desse controle sobre a propriedade municipal e sobre uma série de funções atualmente exercidas pelos burocratas (HOBSBAWN, 1982, 41).

Os intelectuais estavam insatisfeitos apenas com a sua marginalização na sociedade burguesa, portanto, dificilmente poderiam liderar os pequenos burgueses e os trabalhadores pobres, que apesar de numerosos não eram maioria nas cidades e nem possuíam uma ideologia própria. As organizações dos trabalhadores tinham se restringido à experiência dos sindicatos, pois os socialistas e comunistas eram maioria.

Ainda assim, precariamente organizados e alinhados ao jacobinismo, os trabalhadores não tinham ilusão em relação ao capitalismo e conseguiram formular, pelo menos, um objetivo político para sua ação revolucionária: "a república democrática e social", que não deixava de ter um conteúdo utópico, uma vez que as condições históricas para tanto, estavam longe de existir. Só a realização da revolução burguesa poderia gerar as armas para a luta futura do proletariado.

De fato, o triunfo da burguesia não fora o triunfo de uma classe como disse Marx, mas o triunfo de um novo regime social, que se contrapôs contra o velho regime. "A burguesia desempenhou um papel eminentemente revolucionário" que se esgotou na realização de seu projeto de sociedade competitiva de produção e consumo cosmopolitas, de domínio sobre a natureza, a ciência e os homens do campo e da cidade como forças produtivas.

Mas para uma compreensão do processo de amadurecimento político e ideológico do proletariado é necessário analisar o resultado dos embates entre a burguesia e os operários e entre estes, a pequena burguesia e os camponeses no período de hegemonia do Partido da Ordem na França.

A derrocada da Monarquia de Luis Felipe foi uma conquista do proletariado, mas na realidade era a vitória da burguesia industrial sobre a aristocracia financeira, que tinha maioria no governo provisório deixando nitidamente definido o caráter burguês da Republica proclamada pelos operários.

A força revolucionaria dos operários estava restrita a Paris, onde se dava sua maior concentração, portanto, contra ele se levantava a burguesia e a massa da nação - os camponeses e os pequenos burgueses, que constituiriam em diferentes momentos da luta da França forças - contra-revolucionárias.

A burguesia conseguiu conter a influência do proletariado à Comissão de Luxemburgo e os seus objetivos pareciam se diluir diante da propaganda ideológica daquela, como se o Governo Provisório lhe pertencesse. Mas a necessidade que tinha a burguesia de restabelecer o crédito do Estado e o crédito privado deixa à mostra os seus verdadeiros interesses, ao ampliar o poder da aristocracia financeira e ao penalizar o camponês com os impostos diretos e o pequeno burguês com um tipo de empréstimo de suas quantias depositadas nas caixas econômicas. 
A situação de revolta das massas colocou os operários em guarda, no entanto, o Governo Provisório se antecipou às suas ações, criando uma Guarda Móvel constituída pelo lumpen-proletariado, que assegurava o fortalecimento da reação no seio da própria classe operária. Também, foram criadas pelo Governo as Oficinas Nacionais constituídas por operários desempregados como se fossem uma criação da própria Comissão de Luxemburgo, de Luís Blanc.

A arma mais usada pela burguesia é produzir confusão entre os seus adversários, dividindo-os e tornando-os, em parte, seus aliados. Assim, enquanto as Oficinas Nacionais se identificavam cada vez mais com o proletariado, os pequenos burgueses se aliavam à burguesia para combatê-las. Mas, até mesmo o proletariado a ela se uniu de forma equívoca para defender o Governo Provisório, que foi ameaçado pela burguesia numa farsa inimaginável nos dias 17 de março e 16 de abril de 1848.

Os fatos posteriores que culminaram na insurreição de junho de 1848, passando pelas eleições de maio, permitiram acabar com essa farsa da burguesia. A derrota dos operários nas eleições, quando os camponeses e os pequenos burgueses aliaram-se à burguesia; a derrota nas ruas, quando o proletariado foi instigado à luta após a prisão de seus líderes e a expulsão dos operários das Oficinas Nacionais deram ao proletariado e ao povo os verdadeiros contornos da República Burguesa.

Após a insurreição, a Assembléia Nacional Constituinte permaneceu sob o controle da fração republicana da burguesia responsável pelos combates aos adversários. Como aliados tinha as frações monarquistas e os democratas, apesar de terem sido derrotadas.

A ditadura de Cavaignac encarregou-se de destruir as últimas resistências do proletariado e de impor à pequena burguesia o ônus da derrocada financeira da República. Uma vez mais a burguesia revela sua identidade, desorientando a pequena-burguesia que a supunha aliada, tanto que lutou contra o proletariado, para garantir sua vitória nas jornadas de junho.

Apesar da pressão dos pequenos burgueses sobre a Assembléia Nacional, para que se realizassem as concordatas amistosas em lugar da execução de suas dívidas, não houve concessões por parte de Cavaignac, que só em setembro sentiu o seu prestígio abalado com a eleição do Príncipe Luis Bonaparte e do comunista Raspail e de Fould banqueiro e orleanista, como representes de Paris.

No entanto, as suas possibilidades de controle do poder não estavam esgotadas e a sua grande arma estava em gestação: a Constituição Republicana, que apesar de suas contradições manteve-o como presidente até as eleições de novembro, quando foi derrotado por Napoleão.

Napoleão foi eleito pelo proletariado, pela pequena burguesia, pelos camponeses, pela grande burguesia, por todos que queriam derrubar Cavaignac e a sua Assembléia Constituinte.

A derrota de todos os partidos, com exceção do partido burguês republicano, foi a derrota da República e a vitória da Monarquia representada pelos grandes latifundiários (legitimistas) e pela aristocracia financeira (orleanista).

O período de dezembro de 1848 a dezembro de 1851 coloca em cena a disputa entre as forças políticas revolucionárias e reacionárias, que são de certo modo instáveis nos seus propósitos e nas suas estratégias de luta.

Os partidos tradicionais da fração republicana e da fração monarquista defrontaramse com o Partido Social-Democrata (a Montanha) que reunia os operários em coalizão com os pequenos burgueses e em aliança com os socialistas. No entanto, a sua constituição não lhe garantia a hegemonia nem na Assembléia Nacional e nem nos movimentos de massa, o que significava a sua precária organização e definição na luta contra os adversários. 
Na sua primeira tentativa de reação ao Governo de Bonaparte quando Ledru-Rollin propõe o seu impeachment, a Montanha foi derrotada, pois além de ter seu projeto rejeitado, foi desbaratada nas ruas pelas forças de Changarnier, em 13 de junho de 1849, em consequência da traição de pequena burguesia, que vacilou diante da senha de insurreição, não aparecendo com a Guarda Nacional.

Mas, nas eleições de março de 1850, o Partido Social Democrático mostrou-se fortalecido pela aliança do proletariado com a pequena burguesia, elegendo seus candidatos. Essa vitória, no entanto, foi diminuída pelo resultado obtido na eleição complementar de abril.

Esse foi um erro político, como muitos outros cometidos pelo Partido SocialDemocrata, que segundo Marx, muitas vezes exagerava na sua avaliação sobre os meios que dispunha e se iludia diante das situações. Quando, por exemplo, o Partido da Ordem propôs aliança com a Montanha, para rejeitar o pedido de dotação feito por Bonaparte (20/09/1851), ela aceitou e a proposta foi derrotada. No entanto, quando a Montanha propôs anistia geral para os culpados por delitos políticos o Partido da Ordem se recusou a apoiar.

Essa e outras passagens da luta entre Bonaparte e a Assembléia Nacional, ou seja, o Partido da Ordem, que era majoritário até 1850, confundiam o quadro político e desorientavam o Partido Social-Democrata. Afinal, o fato de ter derrotado os Republicanos não colocava Bonaparte ao lado dos monarquistas. Por outro lado, a defesa da República pelo Partido da Ordem não passava de estratégia para camuflar seus objetivos de restauração como revelavam Thiers e Barryer.

A prova mais concreta da posição do Partido da Ordem foi a aprovação da nova lei eleitoral, que alterava as condições do eleitorado e a suspensão do sufrágio universal.

Diante dessas medidas aprovadas em 32 de maio de 1850, não houve reação por parte dos operários e da pequena burguesia. No entanto, Bonaparte defendeu o restabelecimento do sufrágio. É claro, que seu objetivo era muito definido. A sua reeleição é que o motivara a defender essa instituição democrática. Sua proposta foi derrotada pela Assembléia em 1851, bem como também, com o voto da Montanha foi rejeitada a Lei dos Questores, propondo a formação de um exército sob controle do parlamento, para sua defesa e segurança.

O que interessa nessa análise é mostrar como Napoleão se fortaleceu, a ponto de desferir o golpe de Estado de 02 de dezembro de 1851, enquanto o Partido Social Democrata tornava-se incapaz de mobilizar as massas camponesas.

O golpe de Napoleão antecipado pela proposta da Lei de Responsabilidade do Presidente apresentada por Thiers, foi apoiado por duas classes antagônicas: a burguesia industrial e os camponeses.

De fato, essa contradição poderia gerar duas hipóteses em relação ao governo de Bonaparte:

1) A derrubada do Partido da Ordem e o fechamento da Assembléia Nacional foi um golpe sobre a ordem burguesa conservadora;

2) O golpe de Bonaparte apoiado pelos camponeses significava um avanço no sentido da revolução proletária.

No entanto, nenhuma dessas hipóteses se realizou com o desdobramento da estratégia de despotismo bonapartista. $\mathrm{O}$ apoio dos camponeses vinha dos seus segmentos mais conservadores, embora mesmo dos departamentos em que se concentravam camponeses mais revolucionários, Bonaparte tivesse também recebido votos. A eles interessava a consolidação da sua pequena propriedade presa da exploração capitalista. 
Seus interesses divergiam, portanto, da burguesia, na medida em que esta lhe impôs impostos, o domínio dos padres e do exército.

Mas não era intenção de Bonaparte destruir a ordem burguesa, ao contrário ele se apresentava como seu guardião, daí porque protegeu a classe média dos impostos do vinho, aumentou os salários dos funcionários públicos, determinou concessões ferroviárias para criar condições de fortalecimento da indústria e do comércio.

Ao lado dessas medidas, toma outras que poderiam favorecer os camponeses, mas que eram abertamente, uma forma de beneficiamento do capital. Bonaparte cria as facilidades necessárias para o endividamento dos camponeses nos bancos hipotecários, no entanto, os capitalistas discordam dessa medida, porque para esse financiamento seria retirado dinheiro das propriedades confiscadas à Casa de Orleans. Dessa forma, somente o lupem-proletariado que constitui a Sociedade 10 de Dezembro é beneficiado por Bonaparte, através de prêmios da loteria do estado, as porcentagens resultantes da fraude e do suborno.

Nesse contexto seria impossível identificar aproximações entre os interesses de Bonaparte e os do proletariado. Este, além de ter sido impedido de reagir ao golpe, por falta de preparo para enfrentar novamente a burguesia, foi perseguido por Bonaparte que desbaratou as operações operárias existentes.

Embora tivesse sido a única classe a se rebelar através de uma insurreição, como a de junho de 1848, o proletariado não ofereceu nenhuma resistência ou ameaça a Bonaparte, pois além de desarmado, o que o impedia de se confrontar com a Guarda Nacional e a Guarda de Napoleão da Sociedade 10 de Dezembro estava também isolado das massas e enfraquecido Diane dos seus adversários que tinham duas preocupações: conter Napoleão e esmagar as forças revolucionarias.

\section{3 - Lutas ideológicas pela hegemonia política: burguesia $\mathrm{x}$ proletariado no limiar do século XIX}

A publicação do Manifesto Comunista constitui um marco na história do movimento operário, sobretudo, pela caracterização dos interesses de cada classe na sociedade capitalista e pela definição dos fundamentos ideológicos da luta do proletariado, o que possibilitou, a partir daí, um grande avanço ao movimento revolucionário, carente, até então, de uma direção política mais adequada.

A produção socialista, até 1848, foi de fundamental importância para caracterizar a ordem capitalista imposta pela burguesia, mas continha desvios e lacunas, que somente o pensamento marxista pôde retificar, superando suas características burguesas.

O socialismo feudal, o socialismo pequeno-burguês, o socialismo alemão, o socialismo burguês, o socialismo e o comunismo crítico-utópicos analisados criticamente por Marx, contém os reflexos das contradições da ideologia revolucionária do proletariado, que vai se construindo historicamente mediante o desenvolvimento do capitalismo.

$\mathrm{Na}$ sua análise histórica, Marx indica claramente a função do proletariado e os fundamentos concretos de sua ideologia:

De todas as classes que ora enfrentam a burguesia, só o proletariado é uma classe verdadeiramente revolucionária. As outras classes degeneram e perecem com o desenvolvimento da grande indústria; o proletariado, pelo contrário, é o seu produto mais autêntico. As classes médias pequenos comerciantes, pequenos fabricantes, artesãos, camponeses combatem a burguesia porque esta compromete sua existência como classes médias. 
Não são, pois, revolucionárias, mas conservadoras; mais ainda reacionários, pois pretendem fazer girar para trás a roda da história. Quando são revolucionárias é em conseqüência de sua iminente passagem para o proletariado; não defendem então seus interesses atuais, mas seus interesses futuros; abandonam seu próprio ponto de vista para se colocar no do proletariado.

O lumpen-proletariado, esse produto passivo da putrefação das camadas mais baixas da velha sociedade, pode, às vezes, ser arrastado ao movimento por uma revolução proletária; todavia, suas condições de vida o predispõem mais a vender-se à reação.

Nas condições de existência do proletariado já então destruídas as da velha sociedade. $\mathrm{O}$ proletariado não tem propriedade; suas relações com a mulher e os filhos nada têm de comum com as relações familiares burguesas. O trabalho industrial moderno, a sujeição do operário pelo capital, tanto na Inglaterra como na França, na América como na Alemanha, despoja o proletariado de todo caráter nacional. As leis, a moral, a religião, são para ele meros preconceitos burgueses, atrás dos quais se ocultam outros tantos interesses burgueses.

Todas as classes que no passado conquistaram o poder trataram de consolidar a situação adquirida submetendo a sociedade às suas condições de apropriação. Os proletários não podem apoderar-se das forças produtivas sociais senão abolindo o modo de apropriação que era próprio a estas, e, por conseguinte, todo modo de apropriação em vigor até hoje.

Os proletários nada tem de seu a salvaguardar; sua missão é destruir todas as garantias e seguranças da propriedade privada até aqui existentes (MARX, 20)

A derrota das revoluções de 1848 tiveram dois efeitos contraditórios. Por um lado a consolidação da ordem burguesa, sendo admirável e expansão do capitalismo de 1849 a 1870 e a realização dos objetivos políticos do liberalismo; por outro lado, a emergência do proletariado e do socialismo como alternativa política de caráter internacional.

A estrada de ferro, o vapor e o telégrafo foram os fatores mais importantes para a unificação do mercado mundial e para o fortalecimento do liberalismo econômico, gerando melhores condições para a iniciativa privada. Inglaterra, Áustria, Estados Unidos, França, Alemanha completavam entre si suas produções de ferro, algodão, carvão, ouro e, também, tecnologia que começava a lançar as bases para o capitalismo industrial avançado.

Apesar dos conflitos e das guerras, que resultaram do processo de unificação de alguns países como a Alemanha e a Itália, as agitações desse período, com exceção da Comuna de Paris, não tinham caráter revolucionário, pois ao mesmo tempo em que se fortalecia o movimento operário, sobretudo, através das organizações sindicais na Inglaterra, Estados Unidos e Austrália, os governantes tanto nos países que tinham alcançado regimes de representatividade parlamentar, como em países em que prevalecia a monarquia aristocrática (Prússia, Itália), introduziram reformas de cunho liberal mediante o sufrágio universal, de forma a conter o conflito entre o liberalismo e o socialismo; o liberalismo e o nacionalismo.

Naturalmente, o quadro de forças políticas desse período não era tão simples, que se pudesse reduzi-lo ao confronto entre duas classes: a burguesia e o proletariado. Permanecia a divisão entre as classes altas e médias, as camadas intermediárias - pequenos comerciantes, artesãos e outros pequenos burgueses, proprietários camponeses e a classe dos trabalhadores pobres. 
A aristocracia tinha riqueza, poder e influência política inabalável, pois enquanto duravam as monarquias, eram preservadas as instituições nas quais se alojava a aristocracia, como as Câmaras dos Lordes.

As burguesias e as velhas aristocracias rurais tinham riqueza, mas precisavam do apoio dos não-burgueses para elegerem seus representantes. Isso explica porque a burguesia sustentava, enquanto era possível, suas alianças com a pequena burguesia, os trabalhadores e os camponeses. No entanto, progressivamente essa camada intermediária foi se tornando independente.

Na Escandinávia, partidos camponeses separaram-se como "esquerda" (Verstre) em 1848 (Dinamarca) e durante a década de 1860 (Noruega), ou o grupo de pressão agrário anticidade (Suécia, 1867). Na Prússia (Alemanha), os democratas radicais, com sua base no sudoeste nãoindustrial, recusaram-se a seguir os nacionais-liberais burgueses em sua aliança com Bismark depois de 1866, embora alguns deles tendessem a se aliar aos social-democratas marxistas anti-Prússia. $\mathrm{Na}$ Itália os republicanos permaneceram na oposição, enquanto os moderados tornaram-se dominantes do novo reino unificado. Na França, a burguesia, a muito não conseguiu mais comandar sozinha ou mesmo sob a bandeira liberal, e seus candidatos buscavam apoio popular através de rótulos cada vez mais inflamados. "Reforma" e "Progressista" davam lugar a "Republicano" e, este a "Radical", e, na Terceira República, a "RadicalSocialista", cada qual ocultando uma nova geração dos mesmos barbados Sólon, rapidamente mudando para posições moderadas depois de seus triunfos eleitorais com a esquerda. Somente na Inglaterra os radicais permaneceram uma ala permanente do Partido Liberal; provavelmente porque ai não existia, enquanto classe, os camponeses e a pequena burguesia que permitiram aos radicais estabelecerem sua independência política alhures. (HOBSBAWN, 1982, 123)

Essas evidências de crescimento das forças de oposição são significativas, porém nesse estágio recente de superação do feudalismo e do absolutismo eram ainda muito influentes as forças conservadoras. A ordem dos anciens régimes sustentada pela aristocracia e pela Igreja ainda predominava e era determinante no pensamento da época. Para os dirigentes conservadores remanescentes como em Berlim ou em São Petesburgo o problema era como fazer crescer o capitalismo e a burguesia, sem a adoção de um regime político burguês-liberal.

Até mesmo boa parte da "inteligentsia" da época, embora tivesse avançado no sentido da laicização, carregava o ranço do obscurantismo contra a ideologia liberal. A Alemanha, por exemplo, cujo processo de unificação e de desenvolvimento do capitalismo determinou um grande atraso ideológico em relação à Inglaterra e a França, produziu a vitória da reação feudal e as condições para a construção de uma sólida corrente reacionária, que foi do romanticismo ao irracionalismo, representada por expoentes da filosofia alemã como Schopenhauer, Niestzsche, Spengler, Schelling e outros.

Se, de um lado, o conservadorismo continuava hegemônico, por outro, sofria abalos contínuos pelo incontrolável avanço da ciência, da tecnologia e da produção do pensamento político socialista.

A supremacia das ciências naturais era gerada no bojo do desenvolvimento acelerado do capitalismo. Os avanços da Matemática, das Ciências Físicas, da Química, da Mecânica e da Estatística não geraram polêmicas como a Teoria da Evolução de Darwin, 
que rompeu com a tradição secular da ideologia religiosa e com os próprios parâmetros da ciência, ao introduzir o conceito de evolução.

Essa revolução no pensamento científico também eliminou a divisão entre ciências naturais e ciências humanas; tanto que se tornou predominante nas ciências humanas o modelo das ciências experimentais, absorvido por Comte e Spencer na sua filosofia positiva. A concepção de evolucionicismo estava contida na idéia de Comte de que a humanidade atravessava três estágios: teológico, metafísico e científico.

Os progressos inevitáveis de ordem econômica e social comprovaram a concepção evolucionista de Darwin, que foi absorvida por Marx ao contrário dos filósofos alemães reacionários, que atribuíam à força dos altos poderes irracionais o desenvolvimento do capitalismo.

Marx, ao contrário dos pensadores alemães, não estava preocupado em conter as forças do capitalismo liberal que ameaçavam a ordem burguesa. Sua grande preocupação era a forma de transição de uma sociedade pré-capitalista para uma capitalista e dessa para uma sociedade socialista.

Depois das Revoluções de 1848, Marx descartava a possibilidade de uma nova tentativa antes da organização de partidos da classe operária independentes e de massa, o que veio a acontecer, a partir da criação da Associação Internacional dos Trabalhadores A Primeira Internacional (1864/72)

Embora, enfrentando dissidências internas como a tendência anarquista de Bakunin e a tendência radical-democrata de Lassalle, a Internacional, sob a direção de Marx, obteve uma mudança radical na perspectiva do movimento sindicalista, que além de se expandir numericamente, tornou-se independente e diretamente vinculado ao socialismo.

$\mathrm{Na}$ Alemanha, além dos sindicatos, formaram-se dois Partidos, sendo um de orientação Lassaleana e oficialmente radical-democrata, a Assocação Geral dos Trabalhadores Alemães de Lassalle e o Partido Social Democrático sob a direção de Liebknecht e Bebel, que embora mais radicais e socialistas adotaram uma política de aliança com a esquerda democrática (anti-Prússia). Posteriormente esses dois partidos foram fundidos formando o Partido Social Democrata Alemão.

Apesar da derrota em 1848, a ideologia revolucionária fortaleceu-se superando as suas deficiências iniciais, próprias da fase do socialismo utópico.

O Saint-simonismo tinha cortado suas ligações com a esquerda. Havia se transformado no "Positivismo" de Augusto Comte (1798-1857) e numa juvenil experiência levada a termo por um grupo de capitalistas aventureiros, na maioria franceses. Os seguidores de Robert Owen (17711858) tinham voltado suas energias práticas para o modesto campo das lojas cooperativas. Fourier, Cabet e outros inspiradores das comunidades comunistas, sobretudo na terra da liberdade e das oportunidades extraordinárias foram esquecidos. (HOBSBAWN, 1982: 176-77)

Os movimentos revolucionários que se realizaram no período de 48 a 71 foram testando de certa forma a potencialidade das teorias de revolução.

O anarquismo, responsável pela divisão da Internacional em 1879-72, embora tenha tido uma grande influência na França, na Suíça francesa, na Itália e na Espanha não teve maior importância política a não ser nesse último país, pois sua proposta apesar de incendiária, como se revela em Bakunin "A paixão da destruição". (HOBSBAWN, 1982:178), não ultrapassava os limites do cooperativismo, em que estaria eliminado qualquer tipo de governo e do nível de revolta do passado pré-industrial contra a desumanização do capitalismo presente. 
A tendência socialista expressa no radicalismo democrático realizou-se na democracia dos Estados Unidos, prevalecendo muito mais um programa liberal, como expressão das aspirações do homem comum do que o objetivo final de uma democracia revolucionária.

A esquerda tradicional que incluía os republicanos radicais democratas e os jacobinos comunistas blanquistas teve uma ação determinante na França, até a Comuna, porém não superou a prática herdada de junho de 1848, portanto, foi superada no movimento socialista posterior.

Naturalmente, a importância da comuna, cuja realização maior foi a instituição de um governo insurrecional operário, foi a de se constituir como a primeira revolução socialista, embora seu objetivo de criação de cooperativas autônomas fosse fruto do socialismo pré-1848.

Apesar da Internacional não ter se manifestado durante a realização da Comuna, Marx avaliou esse movimento revolucionário, destacando o seu caráter proletário, bem como os seus erros políticos, que poderiam se constituir em lições para o futuro da luta revolucionária.

De fato, com a revolução de setembro de 1870 quando os operários proclamaram a República, destruindo o Império de Napoleão, e com a proclamação da Comuna de Paris em 18 de março de 1871, os trabalhadores conseguiram obter o apoio dos camponeses, que se haviam rebelado contra o Império de Bonaparte, fruto de seu equívoco na eleição de dezembro de 1851. Nas eleições de 30 de abril de 1871, Thiers foi derrotado pelas províncias de quem esperava o apoio para lutar contra Paris.

A ameaça do governo proletário de Paris atraiu para si a evidência da burguesia apoiada por Bismark, como também a reação da maioria dos governos da Europa contra a Associação Internacional dos Trabalhadores.

Para Marx, a vacilação dos revolucionários impediu-os de derrubar Versalhes, o que permitiu a organização da contra-revolução. Por outro lado, o esmagamento do proletariado provou a vulnerabilidade da ordem burguesa, que não pode resistir ao avanço histórico das lutas de classe.

Essa experiência histórica, embora única no século XIX foi posterior a outros movimentos como o Taiping (China - 1850), da Itália (1860), da Polônia (1863) e as Revoluções Espanholas de 1854 e 1868-74, anterior ao movimento mais singular do período, que foi o populismo russo.

Embora não tenha sido um movimento de massa, ele foi o germe do bolchevismo. A importância desse movimento não está no que realizou, mas nas condições que criou para a instalação do socialismo como regime adotado, pela primeira vez num país, após a derrubada do tzarismo, portanto, sem que se realizasse uma revolução burguesa intermediária.

Esse movimento concentrou os intelectuais russos, cuja maioria era de filhos da pequena-burguesia, numa ação revolucionária junto ao povo. O campesinato, única força revolucionária na Rússia, estava tratado pela ideologia da submissão a Deus a ao Tzar. A burguesia era muito débil para ter uma função progressista, pois ocupava os quadros da burocracia e a classe dos negociantes. O proletariado emergente é que poderia com a aliança dos camponeses derrubar a autocracia russa.

Os intelectuais revolucionários apesar de aspirarem a ocidentalização da Rússia única alternativa histórica para o seu atraso, não absorveram as idéias liberais e nacionalistas dos países da Europa e da América. O liberalismo e o nacionalismo estavam contidos nas reformas do czar Alexandre II (1860), portanto, não se apresentavam como uma proposta revolucionária. 
O avanço da "intelligentsia" russa ficou registrado nas obras dos seus grandes escritores e cientistas, que ao contrário de reproduzirem acriticamente as idéias modernas dos países desenvolvidos, criaram idéias próprias e selecionaram no pensamento da época o que existia de mais avançado em termos políticos e sociais. Turgenev, Dostoievsky, Chernishevsky, Belinsky, Alexandre Herzen são alguns dos nomes mais importantes da produção intelectual russa.

Os intelectuais nativistas eram de tradição jacobina-blanqiusta e defendiam para a transformação da Rússia a instituição da vila comunal baseada numa antiga organização social russa. Embora oscilasse entre o anarquismo e a defesa da educação política das massas, prevaleceu no movimento a organização conspiratória secreta.

Os homens e mulheres que agora se juntavam em conspirações secretas para derrubar o tzarismo através de insurreição e terror eram mais do que os herdeiros dos jacobinos ou dos revolucionários profissionais que descendiam desses últimos. Eles iriam quebrar todas as ligações com a sociedade para se dedicar totalmente ao "povo" e à sua revolução, para penetrar no seio do povo e expressar sua vontade. Havia uma intensidade não-romântica, uma totalidade de auto-sacrifício acerca de sua dedicação que não tinha paralelo no Ocidente. (HOBSBAWN, 1982: 182-83)

Ora, considerando o desenrolar da história russa até a revolução de 1917, é possível avaliar a efetividade da ideologia revolucionária e de sua penetração nas massas, o que lhe transforma em força material para a luta de classes.

Na Rússia, a produção ideológica esteve avançada em relação à produção material, pois a transição do comunalismo ao consumismo ocorreu sem que se realizasse o capitalismo industrial avançado.

Outro exemplo da força material da ideologia pode ser buscado no caso da Alemanha, onde a reação burguesa ao socialismo produziu uma ideologia reacionária, cujo apogeu se expressou no totalitarismo de Hitler.

$O$ fato de ser dado, simultaneamente, na Alemanha a luta pela unificação nacional e a luta pela instauração da democracia burguesa gerou um atraso político e social, cujos reflexos se estenderam na formação da ideologia dominante e na desmobilização das massas.

A via prussiana de desenvolvimento da Alemanha praticamente imobilizou as forças revolucionárias. A burguesia não teve um papel revolucionário e a revolução de 1848 caracterizou-se como uma transição com os "velhos poderes", como uma luta contra a tendência radical de origem proletária.

Dessa forma, ao mesmo tempo em que a Alemanha se projeta como um dos países capitalistas mais desenvolvidos permanece atrasado em termos de democratização.

Essa contradição gerava duas alternativas: adequar a estrutura política ao desenvolvimento econômico, o que implicaria na concretização de um movimento revolucionário democrático; ou adaptar a estrutura política sem alterar a estrutura social, às formas já aprovadas nos países ocidentais, ou seja, as formas de democracia parlamentar.

Pero como la relación contradictoria que así creaba entre la economía y la política no impedía el desarrollo del capitalismo en Alemania - y en ello podemos apercibirnos de un modo bien tangible de cuál era el "camino prusiano" que se abría ante el desarrollo del capitalismo alemán - era inevitable que surgiese una ideología basada en la defensa intelectual de esta contradicción entre la estructura económica y la estructura política de Alemania como una etapa de desarrollo más alta, como una posibilidad 
de desarrollo superior a la del Occidente democrático. (LUKÁCKS, 1976, 50).

Algumas concepções, típicas do período que compõem o irracionalismo como corrente do pensamento burgês, apresentou o capitalismo como "destino", o Estado Alemão como instrumento capaz de imprimir direção ao destino cego da economia, através do monarca, como contrapeso irracional necessário para compensar a racionalidade mortífera da economia capitalista.

Nessas concepções está contida a posição radical contra o progresso e a exaltação da trajetória alemã, que conservando a velha ordem soluciona os problemas insolúveis dos Estados ocidentais, inclusive a ameaça do socialismo.

De fato, na Alemanha o movimento operário permaneceu débil depois do período de 1848-49, quando a Nova Gazeta Renana esteve sob a direção de Marx. Conduzido por Lassalle chegou até a apoiar o Estado de Bismark. Nem Liebknecht apresentou uma alternativa revolucionária alinhada à Gazeta Renana, pois defendia o federalismo democrático-burguês, anti-prussiano; nem Franz Mehring, defensor das tradições revolucionárias-democráticas conseguiu aliados.

O movimento operário alemão foi incapaz de aglutinar as forças de esquerda, tanto pelo resultado da influência da ideologia dominante sobre seus líderes, como pelo sectarismo de alguns setores que impediam o avanço da Liga Spartaquista.

A filosofia, a historiografia e a propaganda da corrente burguesa reacionária se encarregaram de defender a idéia do desenvolvimento antidemocrático "especificamente alemão", o único em consonância com a "alma alemã", para justificar a contradição entre o desenvolvimento reacionário da burguesia no campo político social e o desenvolvimento ascendente das forças produtivas.

Nesse sentido o irracionalismo cumpriu sua função.

Es una simples forma de reacción empleando aquí la palabra reaccione en el doble sentido de lo secundario y lo retrógrado) al desarrollo dialéctico del pensamiento humano. Su historia depende, portanto, del desarrollo de la ciencia y de la filosofía, a cuyos nuevos planteamientos reacciona de tal modo, que convierte el problema mismo en solución proclamando la supuesta imposibilidad de principio de resolver el problema como una forma superior de comprender el mundo. Este estilizar la pretendida insolubilidad del problema como la respuesta a él y la pretensión de que en este rehuir la solución y desviarse de ella, en esta evasión ante una respuesta positiva, se contiene la "verdadera" consecución de la realidad, es el rasgo característico decisivo del irracionalismo. (LUKÁCS, 1976, 83)

Naturalmente novas formas de irracionalismo foram gestadas no bojo das lutas impostas de fora à burguesia reacionária, de modo que a concepção de mundo racionalsocialista, que fundamenta o fascismo é diferente do irracionalismo de 1848.

Os acontecimentos de 1917 na Rússia e a penetração de sentimentos anticapitalistas nas massas impõem a rearticulação da ideologia burguesa reacionária.

A ideologia nacional-socialista combina o sentimento de desespero diante da crise com a credulidade e a fé na força criadora de um "gênio ungido pela divindade" (Bismarck, Guilherme II, Hitler), que através de uma subversão radical resolveria todos os problemas. 
A ideologia alemã constituiu-se como o principal inimigo do socialismo. À dialética histórica contrapôs a filosofia intuitiva, à compreensão racional das leis de desenvolvimento da sociedade e dos homens impôs o assalto à razão.

Essa análise superficial das lutas ideológicas na França e na Alemanha confirma a hipótese da efetividade da ideologia revolucionária do proletariado. Somente essa classe na história universal teve condição de opor à concepção de mundo da classe dominante, uma concepção própria e independente.

Nesse sentido é que se apresenta como revolucionária, a sua proposta de uma sociedade socialista, onde finalmente é superada a ordem burguesa, capitalista.

A análise histórica das experiências socialistas existentes atualmente não comporta nesse trabalho, que pretendeu traçar algumas linhas sobre o quadro das lutas ideológicas do século XVIII e XIX.

\section{4 - À Guisa de Conclusão}

Nesse estudo preliminar do qual resultou não um ensaio, mas a minha síntese possível e provisória sobre as lutas ideológicas no processo de mudança social, nos séculos XVIII e XIX, procurei compreender as ideologias da burguesia e do proletariado no momento da sua produção histórica.

Tomando esse ponto de partida, tentei resgatar a trajetória dos embates entre as duas classes nas situações em que o acirramento das lutas sociais conduziu aos movimentos de revolução e contra-revolução.

A opção de não trabalhar com as construções ideológicas já constituídas e com a sua interpretação no pensamento dos diferentes teóricos do liberalismo e do socialismo, resultou da necessidade que tenho de realizar análises históricas que me possibilitem um conhecimento mais orgânico da história mundial.

A dificuldade de abarcar o conteúdo de todo esse período, levou-me a particularizar a situação da França e de forma mais superficial da Alemanha.

Apesar desses limites, foi possível, através dessa análise, reforçar a compreensão do pensamento de Gramsci.

Nesse sentido, a proposição de Gramsci sobre a necessidade histórica da aliança entre operários e camponeses torna-se indiscutível na perspectiva de formação de uma vontade coletiva, com força revolucionária para superação da ordem capitalista.

Nos movimentos revolucionários do século XVIII e XIX, o fracasso das forças progressistas sempre esteve relacionado ao atraso dos movimentos ideológicos das massas, tanto pela desagregação entre operários e camponeses, como pela capacidade de penetração da ideologia burguesa no seio das massas desmobilizadas ideologicamente.

O liberalismo como ideologia dominante da ordem burguesa adquire conteúdo, forma e métodos diversificados, até aparentemente contraditórios, na medida em que a ideologia proletária avança como alternativa teórica e prática para a contradição da sociedade de classes.

Assim, o conteúdo do liberalismo clássico do século XVIII, de caráter revolucionário, enquanto expressão de luta da burguesia com a velha ordem da monarquia absolutista, não é o mesmo do liberalismo do século XIX, quando se efetua a transição do capitalismo concorrencial para o capitalismo monopolista.

O caráter revolucionário da ideologia burguesa é transformado pelo reformismo que predomina na direção política da classe dominante, que tenta diminuir o impasse com o proletariado. Por último, o liberalismo contemporâneo é a síntese de todas as lutas enfrentadas pela burguesia com o proletariado organizado na fase do capitalismo 
monopolista, que se rearticula, em nível mundial, através de um Estado eminentemente intervencionista e regulador, cujo objetivo é manter a ordem capitalista.

Do mesmo modo como o liberalismo se rearticula, também o socialismo adquire historicamente maior efetividade ideológica. O socialismo contemporâneo já superou o seu conteúdo originalmente burguês e utópico, no entanto, não alcançou a penetração maciça no seio das massas, o que permite ao liberalismo se manter como ideologia dominante.

É claro, que as condições concretas de luta entre a burguesia e o proletariado no âmbito do capitalismo monopolista e do imperialismo impõem os avanços e recuos nas lutas ideológicas, no entanto, as indicações teóricas de Marx, Lênin e Gramsci não deixam dúvidas sobre o conteúdo de um programa de ação revolucionária, que vai desde a educação política das massas à organização e prática dos partidos revolucionários; das guerras de posição às guerras de movimento, a partir de análises histórias e práticas que indiquem o grau de correlação das forças sociais, políticas e militares de um país.

Depois da Revolução Russa, as perspectivas de revolução no ocidente tornaram-se nebulosas porque somente ocorreram nos países da América Central e da África, onde o desenvolvimento capitalista pode ser considerado incipiente, apesar de articulado com o capitalismo mundial pela via do imperialismo.

Em países de capitalismo avançado como a Itália, as condições de uma revolução tornaram-se remotas, ainda no período que antecedeu a Segunda Grande Guerra, quando as forças revolucionárias, segundo Gramsci, pretendiam romper a ordem burguesa e concretizar o projeto socialista do PCI.

Em lugar do socialismo instalou-se o fascismo, como expressão de uma ideologia reacionária que ganhou força material como componente do senso comum das massas.

Essas especulações, embora estejam apresentadas de forma superficial, revelam a minha preocupação com o tema da educação - da formação da vontade coletiva - da revolução.

Se é um fato real que as condições de vida dos trabalhadores da cidade e do campo nada tem da ordem capitalista e burguesa, porque nela já se encontram completamente destituídas de bens e propriedades, que forças materiais e ideológicas impedem a formação da vontade coletiva para superação dessa ordem?

É claro, que o princípio de superação de uma sociedade, segundo Marx prevê o esgotamento de todas as suas forças produtivas que engendram as condições de surgimento da nova ordem. No entanto, para que elas atinjam esse nível de desenvolvimento não se pode admitir uma concepção economicista e espontaneísta, pouco dialética, que entende esse desenvolvimento como sendo mecânico e irreversível.

O "automatismo" histórico de determinadas premissas (a existência de determinadas condições objetivas) é potenciado politicamente pelos partidos e pelos homens capazes: a sua ausência de deficiência (quantitativa e qualitativa) torna estéril o próprio "automatismo" (que, portanto, não é automatismo). As premissas existem abstratamente, mas as conseqüências não se verificam porque falta o fator humano. Por isso pode-se dizer que os partidos têm a missão de criar dirigentes capazes, são a função de massa que seleciona, desenvolve, multiplica os dirigentes necessários para que um grupo social definido (que é uma quantidade "fixa", na medida em que se pode estabelecer quantos são os componentes de cada grupo social) se articule, e, de caos tumultuado, transforme-se em exército político organicamente predisposto. (GRAMSCI, 1980, 86) 
Gramsci, assim como Marx, privilegiou a luta política como estratégia revolucionária e nesse sentido atribuiu ao partido a função de construção do bloco histórico capaz de romper a hegemonia da classe dirigente no poder.

Ora, é a construção desse bloco histórico que inclui necessariamente a educação política das massas, a aliança entre trabalhadores do campo e da cidade e a formação da vontade coletiva.

Resta aos educadores como parte desse bloco histórico inserir sua política pedagógica no âmbito da luta política do proletariado, mas até o momento o único elemento de consenso entre os "educadores progressistas" está na indagação comum: o que fazer?

\section{Bibliografia}

FERNANDES, Florestan. A sociologia numa era de revolução social. Rio de Janeiro, Zahar, 1976.

GRAMSCI, A. Concepção Dialética da História. Rio de Janeiro. Civilização Brasileira, 1981. 1980.

Maquiavel, a política e o estado moderno. Rio de Janeiro, Civilização Brasileira,

HOBSBAWN, E. A era das revoluções: 1789-1848. Rio de Janeiro, Paz e Terra, 1981. A Era do Capital: 1848 - 1875. Rio de Janeiro, Paz e Terra, 1982.

LUKACS, G. El asalto a La razón. Barcelona, Grijalbo, 1976.

MARX, K. \& ENGELS, F. Obras escolhidas. São Paulo, Alfa-Omega, v. 1 A ideologia alemã I. Lisboa, Presença, 1980.

Notas:

\footnotetext{
${ }^{1}$ Texto inicialmente produzido em 1986, durante Doutorado em História da Educação na Unicamp. Reflexão atualizada no contexto da primeira década do século XXI.

2 Atuou como docente na Universidade Estadual do Maranhão, Universidade Federal do Maranhão e Universidade Estadual de Campinas. Atualmente, realiza pesquisas e coordena no Maranhão o Grupo de Pesquisa História, Sociedade e Educação no Brasil (HISTEDBR).Tem estudos e pesquisas na área de Educação, com ênfase em Filosofia e História da Educação, dedicando-se aos seguintes temas: política educacional, historiografia, história da educação, administração educacional e financiamento da educação básica.
}

Recebido em: $\quad$ 15/12/10

Aprovado em: $\quad$ 20/02/11 